\title{
HISTOLOGY OF THE VAGINAL EPITHELIUM OF THE SOW DURING ORAL ADMINISTRATION OF METHALLIBURE (ICI 33828)
}

\author{
A. E. WRATHALL \\ Ministry of Agriculture, Central Veterinary Laboratory, Weybridge, Surrey
}

(Received 27th November 1968)

\begin{abstract}
Summary. Serial vaginal biopsies were taken from sows receiving 100 or $150 \mathrm{mg}$ methallibure daily (Groups 1 and 2), from untreated pregnant sows following mating (Group 3 ) and from untreated, unmated sows (Group 4). Group 1 received methallibure from the 2nd day of oestrus (Day 0 ) for 30 days and Group 2 received similar treatment for 20 days from Day 11 of the cycle. The biopsies were examined histologically for their general character and the number of epithelial cell layers was recorded. During Days 9 to 14 (di-oestrous period), there were no significant differences between the number of epithelial cell layers in the four groups. During Days 19 to 24 (oestrous period), there were no significant differences between Groups 1,2 and 3 but all these groups were significantly different from Group $4(P<0 \cdot 001)$. The values on individual days in the oestrous period in Groups 1,2 and 3 were also significantly different from Group $4(P<0 \cdot 01)$.

The findings are discussed in relation to the mode of action of methallibure and to the vaginal biopsy method of pregnancy diagnosis in pigs.
\end{abstract}

\section{INTRODUCTION}

ICI Compound 33828, now known as methallibure, is a dithiocarbamoylhydrazine derivative which suppresses oestrus and ovulation in pigs (Polge, 1965). When administered orally in the food, it affords an effective and practical method for synchronization of the oestrous cycle and it is used commercially for that purpose in the pig industry. Methallibure appears to act by inhibiting the output of gonadotrophins from the anterior pituitary (Paget, Walpole \& Richardson, 1961 ; Parkes, 1963) but it does not affect the life-span of current corpora lutea, at least in the pig (Polge, 1965).

There have been several reports describing the use of vaginal biopsies to study vaginal histology during various physiological states in the pig; for a review of these see Busch (1966) and also de Bois, Muurling \& Wensing (1965), O'Reilly (1967), Walker (1967) and Done \& Heard (1968). Most of these workers have been primarily interested in developing a reliable method for pregnancy diagnosis in the sow and have therefore compared vaginal biopsies in pregnancy with those taken during various stages of the oestrous cycle. In brief, they found 
that, when sectioned vertically to the surface, the vaginal epithelium assumed a characteristic appearance by about the 30 th day of pregnancy, becoming two to three cells deep and arranged as regular parallel rows of cuboidal or flattened cells. During oestrus they found the epithelial depth to be ten to twenty cells and in di-oestrus, three to five cells, which were not regularly arranged. Busch (1966) has, in addition, described vaginal changes which followed ovariectomy and subsequent treatment with certain steroid hormones. The present report is concerned with the changes in vaginal epithelium during administration of methallibure and a comparison of these changes with those of the normal oestrous cycle and early pregnancy.

\section{MATERIALS AND METHODS}

\section{Animals}

Six Large White/Landrace cross-bred gilts weighing 110 to $180 \mathrm{~kg}$ were used. They were housed and fed in individual pens and were examined twice daily for signs of oestrus by visual inspection and the 'back-pressure' test. The last day of oestrus on each occasion was designated Day 0 . All the animals had experienced several 21-day oestrous cycles before treatment was commenced. Three animals were used in each treatment group.

\section{Treatments}

Methallibure, which was supplied as a $1 \%$ pre-mix in talc, was thoroughly mixed with dry pig meal at the rate of $100 \mathrm{mg}$ methallibure $/ 1.4 \mathrm{~kg}$ meal. The daily amount of meal given, and hence the dose of methallibure, depended upon body weight; those gilts weighing less than $150 \mathrm{~kg}$ received $1.4 \mathrm{~kg}$ meal (100 $\mathrm{mg}$ methallibure) and those of more than $150 \mathrm{~kg}$ received $2 \cdot 1 \mathrm{~kg}$ meal $(150 \mathrm{mg}$ methallibure). These daily quantities were divided into equal morning and afternoon feeds. Control animals during the oestrous cycle and early pregnancy received similar amounts of unmedicated food.

Vaginal biopsies were taken during feeding between 08.00 and 09.00 hours on each selected day with a rotary action biopsy instrument (Morton \& Rankin, 1969). The instrument was sterilized by boiling before use. Restraint of the pigs was never necessary during the operation, the biopsies being taken consecutively on successive occasions from the (1) right lateral, (2) left lateral, (3) dorsal, and (4) ventral walls of the anterior vagina and then immersed immediately in alcoholic Bouin's fixative (Gray, 1954). After $24 \mathrm{hr}$, the biopsies were cut transversely into three blocks, embedded in paraffin wax and sectioned at $5 \mu$. Three sections were cut from each block of tissue, giving a total of nine sections from each biopsy. The sections were stained with Ehrlich's haematoxylin and eosin and mounted in DPX.

\section{Experimental procedure}

Four groups of pigs were used, two methallibure-treated groups, one control group undergoing oestrous cycles and another control group in the first stages of pregnancy. Each group contained three pigs, one group being used three times, the other group being used only once, making a total of six pigs. The treatments were carried out in the following order: 
Group 1. Methallibure administration commenced on the 2nd day of oestrus (Day 0) and was continued for 30 days. Vaginal biopsies were taken at intervals of not more than 3 days during treatment and every day from Day 19 to Day 30 .

Group 2. Methallibure administration commenced on the 11th day of the oestrous cycle (Day 11) and was continued for 20 days. Vaginal biopsies were taken at intervals of not more than 3 days during treatment and every day from Day 20 to Day 27.

Group 3. After completion of methallibure treatment in Group 1, the three pigs were mated at the first oestrus and vaginal biopsies were taken at frequent intervals for the first 30 days of pregnancy.

Group 4. After farrowing of the pigs in Group 3, all the piglets were removed within a week. The first oestrus occurred between 17 and 19 days later and vaginal biopsies were then taken on the days immediately preceding the second post-weaning oestrus and daily for the 25 days following that oestrus.

\section{Histological evaluation of vaginal biopsies}

When all the biopsy sections from a group had been processed, the slides were coded and examined. In every biopsy section, the number of epithelial cell layers was counted in the shallowest intact portion and the average of as many points as possible was recorded. All technically acceptable sections were read. In general, there was no difficulty in making an assessment of the number of layers. Biopsies where the epithelium was between two and three layers of cells were recorded as 2.5 layers. This type of epithelium was usually of a characteristic nature; an incomplete row of flattened cells with condensed nuclei being present between the stratum germinativum and the surface layer. Other data recorded from histological sections of each biopsy were epithelial cell arrangement and type, presence or absence of crypts, degree of mitosis and leucocytic infiltration, and quantity of mucus. This enabled the observer to make a general assessment of the normality, or otherwise, of the tissue.

\section{RESULTS}

The number of vaginal epithelial cell layers recorded during methallibure treatment is shown graphically in Text-fig. 1. The mean and range of values obtained can be compared with those of the two control groups. Table 1 gives the mean values for the three pigs in each of the four groups in two selected periods of 6 days. The first period is Day 9 to Day 14 which was during dioestrus in Group 4 and is called the 'di-oestrous period'. The second period is Day 19 to Day 24 which was during pro-oestrus, oestrus and metoestrus in Group 4 and is referred to as the 'oestrous period'. There are no significant differences between the mean values of the four groups over the di-oestrous period, neither are there any significant differences between Groups 1, 2 and 3 over the oestrous period. However, for the oestrous period the mean values for all these three groups are significantly lower than the corresponding mean for Group $4(P<0 \cdot 001)$. On the individual Days 20 to 24 , the mean values for Groups 1,2 and 3 are also significantly lower than those for Group $4(P<0.01)$. It is clear, therefore, that during the luteal phase of the cycle, the vaginal 


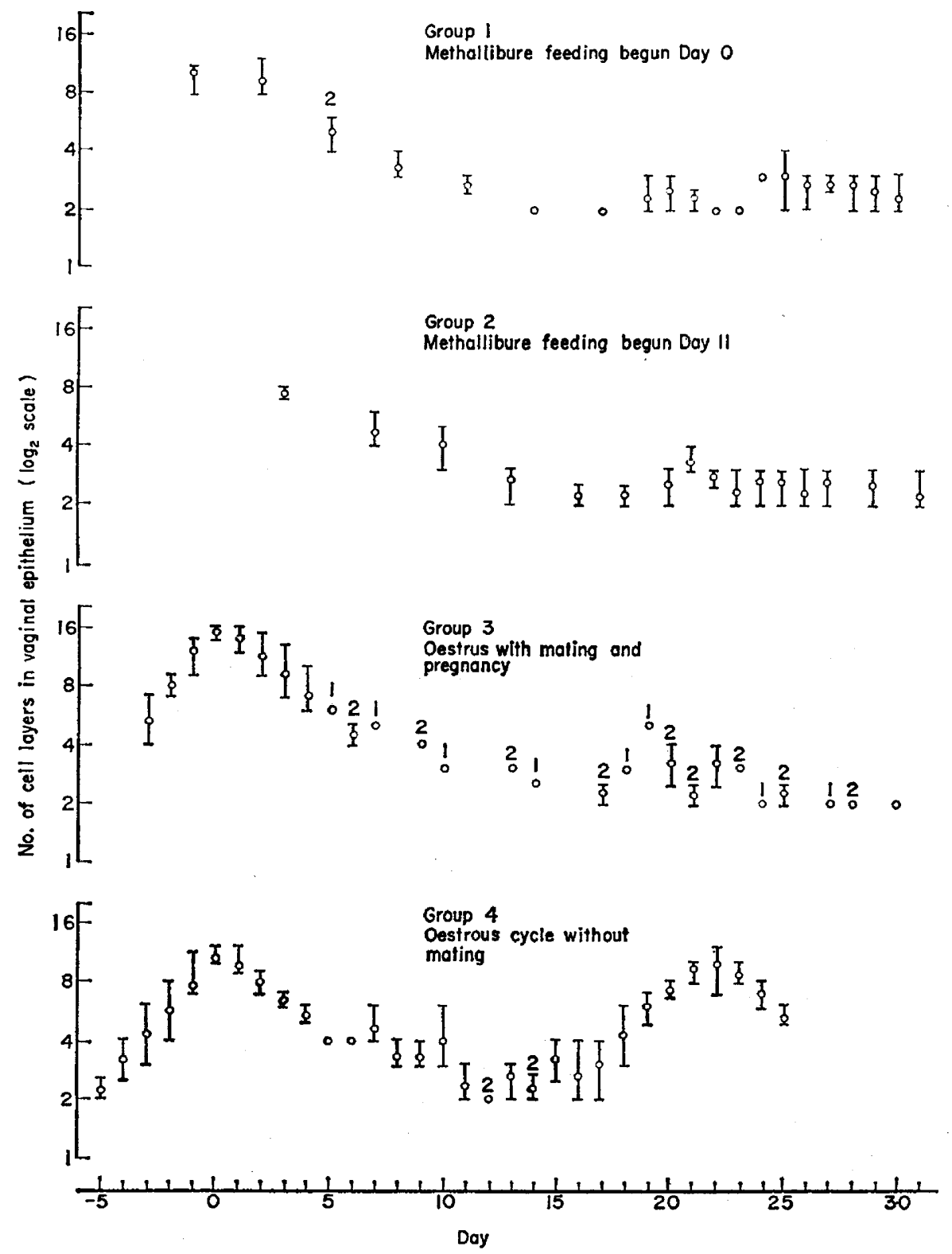

TEXT-FIG. 1. Graph showing number of cell layers in the vaginal epithelium during periods of treatment with methallibure; during oestrus with mating and pregnancy; and during the normal oestrous cycle. Except where one or two values only were available (indicated by small numerals), the mean and range of values, given by circle and vertical bar respectively, are from groups of three pigs. 
epithelium of sows undergoing methallibure treatment did not differ from that of unmated and pregnant sows at the same stage. During the oestrous period, however, the increase in epithelial depth which occurred in the unmated group was suppressed in the methallibure and pregnant groups. In Group 3, as well as in Groups 1 and 2, a tendency towards an irregular epithelial type appeared at the expected time of the next oestrus. This seemed to be more marked in the pregnant pigs (Group 3) than in the methallibure-treated groups although the difference was not statistically significant.

The only untoward effect noted from the repeated vaginal biopsies was mild vaginitis in one pig in Group 4 on Days 6 and 7. This was diagnosed histologically

\section{TABLE 1}

NUMBER OF GELL LAYERS IN VAGINAL EPITHELIUM OF SOWS DURING METHALLIBURE ADMINISTRATION, EARLY PREGNANCY AND THE NORMAL OESTROUS GYGLE (MEAN VALUES OF THREE PIGS UNLESS SPEGIFIED BY NUMBERS IN PARENTHESES)

\begin{tabular}{|c|c|c|c|c|c|}
\hline \multirow{2}{*}{\multicolumn{2}{|c|}{ Day }} & Group 1 & Group 2 & Group 3 & Group 4 \\
\hline & & $\begin{array}{c}\text { Methallibure } \\
\text { begun } \\
\text { Day } 0\end{array}$ & $\begin{array}{c}\text { Methallibure } \\
\text { begun } \\
\text { Day } 11\end{array}$ & $\begin{array}{l}\text { Cycle with } \\
\text { oestrus and } \\
\text { pregnancy }\end{array}$ & $\begin{array}{l}\text { Normal } \\
\text { oestrous } \\
\text { cycle }\end{array}$ \\
\hline $\begin{array}{l}\text { Di-oestrous } \\
\text { period }\end{array}$ & $\begin{array}{r}9 \\
10 \\
11 \\
12 \\
13 \\
14\end{array}$ & $\begin{array}{c}- \\
- \\
2 \cdot 7 \\
- \\
- \\
2 \cdot 0\end{array}$ & $\begin{array}{c}\overline{4} \\
4 \cdot 0 \\
- \\
2 \cdot 7 \\
-\end{array}$ & $\begin{array}{l}4.0(2) \\
3.0(1) \\
= \\
= \\
3.0(2) \\
2.5(1)\end{array}$ & $\begin{array}{l}3 \cdot 3 \\
4 \cdot 0 \\
2 \cdot 3 \\
2 \cdot 0(2) \\
2 \cdot 7 \\
2 \cdot 2(2)\end{array}$ \\
\hline \multicolumn{2}{|c|}{ Mean (Days 9 to 14) } & $2 \cdot 333$ & $3 \cdot 333$ & $3 \cdot 125$ & $2 \cdot 819$ \\
\hline $\begin{array}{r}\text { Oestrous } \\
\text { period }\end{array}$ & $\left\{\begin{array}{l}19 \\
20 \\
21 \\
22 \\
23 \\
24\end{array}\right.$ & $\begin{array}{l}2 \cdot 5(2) \\
2 \cdot 3 \\
2 \cdot 5 \\
2 \cdot 3 \\
2 \cdot 3 \\
3 \cdot 0(2)\end{array}$ & $\begin{array}{l}- \\
2 \cdot 5 \\
3 \cdot 3 \\
2 \cdot 8 \\
2 \cdot 3 \\
2 \cdot 7\end{array}$ & $\begin{array}{l}5 \cdot 0(1) \\
2 \cdot 8 \\
2 \cdot 2(2) \\
3 \cdot 2 \\
3 \cdot 0(2) \\
2 \cdot 0(1)\end{array}$ & $\begin{array}{r}6 \cdot 0 \\
7 \cdot 3 \\
9 \cdot 3 \\
10 \cdot 0 \\
8 \cdot 7 \\
6 \cdot 7\end{array}$ \\
\hline \multicolumn{2}{|c|}{ Mean (Days 19 to 24 ) } & $2 \cdot 500$ & $2 \cdot 750$ & $3 \cdot 042$ & $8 \cdot 000$ \\
\hline
\end{tabular}

and did not have any observed systemic effect. Any harmful effect might have been expected to interfere with pregnancy in Group 3; however, the gestation lengths were within the normal range and the numbers of piglets born were ten, eight and nine respectively. One mummified piglet was also born with the litter of eight.

\section{DISGUSSION}

Paget et al. (1961) noted that cyclical changes in vaginal smears of rats ceased when methallibure was given orally and smears of di-oestrous type persisted for as long as dosing was continued. The compound might have been expected to have a similar effect on the vagina of the sow but the fact has not previously been reported. This vaginal effect presumably reflects the absence of ovarian activity which has been reported by Polge (1965) and is indirectly attributable 
to the inhibition by methallibure of gonadotrophin production by the anterior pituitary.

At the beginning of the present study, it was not known if repeated biopsy of the vagina at short intervals would be harmful to the sow and/or eventually result in damaged vaginal mucous membrane. Since, over the relevant period this does not appear to have been the case, the method could apparently provide a useful means of following the effects of other substances which, directly or indirectly, produce changes in the vagina of the sow.

A further practical point concerns the vaginal changes in the control Group 4 during the oestrus cycle. In these pigs, the number of epithelial layers fell during di-oestrous to two or three on Days 11 to 14 and the epithelium at this period was histologically indistinguishable from the type normally associated with pregnancy (Done \& Heard, 1968). The numbers of epithelial layers throughout the cycle in this group are rather fewer than those recorded by previously mentioned workers and this may reflect the time when the Group 4 biopsies were taken, i.e. early post partum. Nevertheless, as Walker (1967) has also pointed out, pregnant-type epithelium occurs during di-oestrus in some pigs, a fact which should be borne in mind when selecting suitable times for pregnancy diagnosis by vaginal biopsy in this species. Although the view of most workers is that 30 days after mating is a suitable time for accurate diagnosis, the present work indicates that by 32 to 35 days diagnosis may be unreliable, since by then a complete oestrous cycle of 21 days, plus 11 to 14 days, could have elapsed since an unsuccessful mating.

\section{AGKNOWLEDGMENTS}

The author is grateful to Miss C. N. Hebert for the statistical analysis and to Mrs A. Rogers and Mrs E. Cowlard for technical assistance. The supply of methallibure by Imperial Chemical Industries Ltd is also gratefully acknowledged.

\section{REFERENCES}

Busch, W. (1966) Die periodischen Veränderungen des Vaginalepitnels beim Schwein und die Möglichkeit ihrer Heranziehung zur Graviditatsdiagnose. Wiss. Z. Humboldt-Univ. Berl. 15, 833.

DE Bois, G. H. W., Muurling, F. \& Wensing, C. J. W. (1965) Histologisch drachtigheidsonderzoele bij

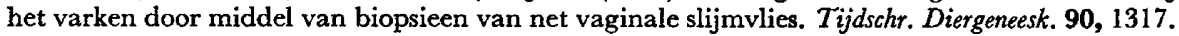

Done, J. T. \& Heard, T. W. (1968) Early pregnancy diagnosis in the sow by vaginal biopsy. Vet. Rec. 82, 64.

Gray, P. (1954) The microtomist's formulary and guide, p. 224. Constable, London.

Morton, D. B. \& RankIn, J. E. F. (1969) The histology of vaginal epithelium of the sow in oestrus and its use in pregnancy diagnosis. Vet. Rec. 84, 658.

O'Reilly, P. J. (1967) Studies on the vaginal epithelium of the sow and its application to pregnancy diagnosis. Ir. vet. F. 21, 234.

Paget, G. E., Walpole, A. L. \& Richardson, D. N. (1961) Non-steroid inhibitors of pituitary gonadotrophic function. Nature, Lond. 192, 1191.

Parkes, A. S. (1963) Review of work with ICI compound 33828: a non-steroidal pituitary inhibitor. $\mathcal{F}$. Reprod. Fert. 5, 459.

Polge, G. (1965) Effective synchronization of oestrus in pigs after treatment with ICI compound 33828. Vet. Rec. 77, 232.

WALKER, D. (1967) Diagnosis of pregnancy in pigs by examination of vaginal mucosae. Vet. Rec. 81, 648 . 